\title{
PENERAPAN METODE QUANTUM TEACHING DALAM MENINGKATKAN MOTIVASI BELAJAR IPS MATERI KERJA SAMA INTERNASIONAL PADA SISWA KELAS IX-A SMP NEGERI 12 TANJUNG BALAI \\ TAHUN AJARAN 2014/2015
}

\author{
Robinhod Silaen* \\ Guru Bidang Studi Ilmu Pengetahuan Sosial, SMP Negeri 12Tanjung Balai
}

\begin{abstract}
ABSTRAK
Tujuan dari penelitian ini adalah untuk meningkatkan motivasi belajar siswa dengan menggunakan metode Quantum teaching pada pokok bahasan Materi Kerja Sama Internasional Kelas IX-A SMP Negeri 12 Tanjung Balai Tahun Ajaran 2014/2015. Dengan menggunakan metode Quantum Teaching dalam pembelajaran IPS maka proses pembelajaran akan dapat berjalan dengan aktif dan menyenangkan serta dapat meningkatkan motivasi dan hasil belajar siswa. Jenis penelitian ini adalah penelitian tindakan kelas. Pendekatan yang digunakan adalah pendekatan kualitatif. Dimana penelitian memaparkan pengaruh metode Quantum teaching terhadap motivasi dan hasil belajar siswa pada pelajaran IPS pokok bahasan Kerja Sama Internasional. Subjek penelitian ini adalah seluruh siswa kelas Kelas IX-A SMP Negeri 12 Tanjung Balai yang berjumlah 30 orang. Alat yang digunakan dalam pengumpulan data pada penelitian ini adalah lembaran observasi, wawancara dan catatan lapangan. Berdasarkan hasil penelitian maka dapat disimpulkan hal sebagai berikut: dapat diketahui motivasi belajar siswa pada siklus I menunjukkan bahwa sebesar 55\% siswa yang memiliki indikator tekun menghadapi tugas, 50\% siswa yang memiliki indikator ulet menghadapi kesulitan, $60 \%$ siswa yang memiliki indikator menunjukkan minat yang tinggi terhadap berbagai macam masalah, $40 \%$ siswa yang memiliki indikator bekerja mandiri, 39\% siswa yang memiliki indikator dapat mempertahankan pendapatnya, 58\% siswa yang memiliki indikator bekerja sama dalam mencari dan memecahkan masalah soal-soal. Dengan demikian, setelah diadakan tindakan pada saat proses pembelajaran dapat disimpulkan pada hasil tindalan siklus II yaitu sebesar $84 \%$ siswa yang memiliki indikator tekun menghadapi tugas, 77\% siswa yang memiliki indikator ulet menghadapi kesulitan, $83 \%$ siswa yang memiliki indikator menunjukkan minat yang tinggi terhadap berbagai macam masalah, $78 \%$ siswa yang memiliki indikator bekerja mandiri, $69 \%$ siswa yang memiliki indikator dapat mempertahankan pendapatnya, $91 \%$ siswa yang memiliki indikator bekerja sama dalam mencari dan memecahkan masalah soal-soal. Secara garis besar dapat disimpulkan bahwa metode Quantum teaching adalah metode yang mampu menuntun siswa untuk meningkatkan motivasi belajar.
\end{abstract}




\section{PENDAHULUAN}

Penyelenggaraan Pendidikan merupakan tanggung jawab bersama antara pemerintah, masyarakat dan keluarga. Masing-masing memiliki peran yang sangat besar dalam rangka mewujudkan tujuan Pendidikan. Keberhasilan penyelenggaraan Pendidikan merupakan keberhasilan bersama. Tidak bisa salah satu pihak menyatakan dirinya sebagai yang paling berhasil dalam penyelenggaraan Pendidikan.

Kesadaran orang tua, dan masyarakat dalam mendukung pelaksanaan kegiatan Pendidikan sangat diperlukan. Setiap orang tua harus mampu memberikan motivasi yang besar kepada anak-anaknya untuk mengikuti kegiatan pembelajaran di sekolah. Sedangkan warga masyarakat juga harus dapat menciptakan kondisi lingkungan yang kondusif sehingga setiap anak selalu berusaha untuk dapat melakukan kegiatan belajar dengan aman dan nyaman.

Dalam proses belajar mengajar motivasi merupakan salah satu hal yang sangat dibutuhkan untuk mendukung proses belajar mengajar itu sendiri karena motivasi merupakan suatu keadaan atau kondisi yang mendorong, merangsang, atau menggerakkan seseorang untuk melakukan sesuatu atau kegiatan yang dilakukannya sehingga ia dapat mencapai tujuannya. Rendahnya motivasi belajar siswa di SMP terhadap mata pelajaran IPS selama ini menandakan bahwa pembelajaran IPS kurang menarik. Selain motivasi yang dapat mendukung pembelajaran, pemahaman terhadap konsep pembelajaran IPS juga sangat penting namun kebanyakan siswa masih kurang memahami konsep pelajaran IPS yang mereka anggap pelajaran IPS adalah pelajaran yang hanya bisa dipelajari dengan menghafal sehingga siswa merasa bosan dan tidak memahami konsep pelajaran IPS.

Dalam pelajaran IPS, dengan materi pelajaran yang cukup padat dan sering berganti materi karena mengikuti perkembangan Kurikulum, juga menjadi beban yang cukup berat bagi siswa untuk dapat berprestasi secara maksimal. Siswa kurang berminat dalam mengikuti pelajaran IPS, hasil yang diperoleh selalu kurang sesuai dengan yang diharapkan.

Mata Pelajaran IPS bertujuan untuk mengenal konsep-konsep dan kehidupan masyarakat dan lingkungannya serta memiliki kemampuan dasar untuk berpikir logis dan kritis dalam memecahkan masalah yang terjadi dimasyarakat.

Melihat kondisi riil di sekolah dan memahami tujuan yang diharapkan dalam pembelajaran IPS, perlu dilakukan upaya secara serius dan terus menerus agar kegiatan pembelajaran dapat berjalan dengan baik. Sehingga aktifitas belajar semakin meningkat dan prestasi belajar siswa juga semakin sesuai dengan yang diharapkan semua pihak.

Tetapi melihat kenyataan dewasa ini apa yang menjadi harapan guru terhadap proses pembelajaran dikelas masih sangat jauh dari yang diharapkan. Berbagi metode dan strategi telah dilakukan namun partisipasi atau aktifitas siswa sangat kurang sehingga apa yang menjadi sasaran atau tujuan pembelajaran tidak dapat dicapai.

Kondisi tersebut juga terjadi pada siswa kelas IX - A SMP Negeri 12 Tanjung Balai pada semester genap tahun pelajaran 2014/2015. Dimana dalam pengamatan awal penulis melihat bahwa hanya sekitar $57 \%$ siswa yang aktif dalam proses pembelajaran. Untuk mengatasi hal tersebut diperlukan usaha dari guru untuk dapat meningkatkan aktifitas belajar siswa kearah yang lebih 
menyenangkan dengan jalan memilih metode atau strategi pembelajaran yang tepat.

Rendahnya minat membaca siswa terhadap buku pelajaran IPS juga tentunya menjadi hambatan dalam proses pembelajaran. Karena bagaimana siswa dapat memahami materi tanpa mereka membaca buku pelajarannya sedangkan jika guru menjelaskan materi didalam proses pembelajaran pun mereka masih banyak yang tidak mendengarkan penjelasan dari guru.

Interaksi antara guru dengan siswa juga sangat berperan penting dalam proses pembelajaran. Namun pada kenyataan di lapangan interaksi antara guru dengan siswa sangat kurang, dimulai dari guru yang menjelaskan materi pelajaran hanya dengan menggunakan metode ceramah tanpa kembali bertanya pada siswa apakah mereka telah mengerti materi yang di jelaskan agar bisa menyelesaikan pertanyaan maupun tugas yang selanjutnya akan diberikan. Begitupun sebaliknya siswa yang kurang berinteraksi dengan gurunya misalnya siswa tidak mendengarkan penjelasan dari guru dan hanya bermain dengan temannya, siswa juga kurang berani bertanya pada guru tentang materi yang diajarkan, karena siswa merasa takut pada gurunya ataupun bahkan siswa memang tidak mau bertanya karena sudah merasa bosan dalam proses pembelajaran disebabkan guru hanya menggunakan metode ceramah dalam proses pembelajaran.

Sesuai pengelaman peneliti di kelas IX - A SMP Negeri 12 Tanjung Balai bahwa dalam mengajarkan IPS peneliti sekaligus guru IPS cenderung menggunakan metode ceramah saja sehingga siswa merasa bosan pada saat guru menjelaskan pelajaran, kurang tekun dalam mengerjakan tugas yang diberikan oleh guru, tidak suka bekerja mandiri, serta tidak berani bertanya terhadap materi yang belum dipahami sehingga siswa kurang termotivasi dalam belajar.

Jika guru tetap menggunakan metode ceramah dalam proses pembelajaran IPS maka siswa akan terus merasa bosan jika belajar IPS, karena metode ceramah hanya bersifat menjelaskan materi dan menyuruh siswa hanya mendengarkan penjelasan yang disampaikan materi oleh guru tanpa ada interaksi lain dari siswa misalnya bertanya, menyampaikan pendapat maupun menjawab pertanyaan secara lisan. Kenyataan dilapangan guru hanya menggunakan metode ini dalam pembelajaran sehinnga siswa merasa bosan dan tidak termotivasi dalam belajar IPS.

Berbagai upaya telah dilakukan untuk dapat meningkatkan motivasi serta prestasi belajar siswa, antara lain dengan pemberian pelajaran tambahan pada kelas, penyediaan LKS yang dilengkapi dengan sejumlah soal-soal latihan, memberikan hafalan tentang materi yang telah diajarkan tetapi hasilnya masih belum memuaskan. Karena siswa merasa bosan dengan pelajaran IPS dan tidak memiliki motivasi jika belajar IPS.

Dari kenyataan tersebut dapat diduga penyebab mengapa motivasi belajar siswa rendah pada setiap ulangan IPS, antara lain: Rendahnya motivasi belajar siswa pada pelajaran IPS,Siswa kurang memahami konsep pengajaran IPS, Minat membaca siswa terhadap buku IPS sangat rendah, Kurangnya interaksi guru dengan siswa pada saat proses pembelajaran, Pada umumnya banyak siswa yang tidak berani untuk bertanya kepada guru tentang materi yang belum mereka ketahui, Guru hanya menggunakan metode ceramah pada saat mengajar.

Dari sejumlah permasalahan tersebut di atas sebenarnya ada satu masalah utama yang perlu mendapat perhatian, yaitu yang berkaitan dengan motivasi siswa 
pada pelajaran IPS. Sebagian besar siswa kurang termotivasi dalam belajar IPS disebabkan guru yang masih menggunakan metode ceramah sehingga materi yang diajarkan menjadi verbal/hafalan. Kita menyadari bahwa salah satu kelemahan metode ceramah jika diterapkan secara murni adalah tidak melibatkan anak didik secara aktif dalam proses pembelajaran akibatnya materi tersebut menjadi kurang menarik.

Upaya yang diperkirakan dapat meningkatkan motivasi siswa pada pelajaran IPS adalah dengan menerapkan metode quantum teaching. Metode quantum teaching adalah sebuah program yang mengizinkan pendidik untuk memahami perbedaan gaya pembelajaran para siswa didalam kelas. Peran guru disini adalah sebagai motivator, artinya guru sebagai pemandu agar siswa belajar secara aktif, kreatif dan akrab dengan suasana pembelajaran di kelas. Metode quantum teaching pada pengajaran IPS menjadi sarana meningkatkan kemampuan siswa untuk memahami, berpartisipasi, berfokus dan menyerap pelajaran yang telah diberikan. Dengan demikian tentu siswa akan lebih termotivasi dalam belajar. Dari latar belakang diatas penulis merasa tertarik mengadakan penelitian dengan judul "Penerapan Metode Quantum Teaching untuk Meningkatkan Motivasi Belajar IPS Materi Kerja Sama Internasional Pada Siswa Kelas IXA SMP Negeri 12 Tanjung Balai Tahun Ajaran 2014/2015".

\section{METODE PENELITIAN}

Jenis penelitian ini adalah penelitian tindakan kelas. Pendekatan yang digunakan adalah pendekatan kualitatif. Dimana penelitian memaparkan pengaruh metode Quantum teaching terhadap motivasi dan hasil belajar siswa pada pelajaran IPS pokok bahasan Kerja Sama Internasional.

Subjek penelitian ini adalah seluruh siswa kelas Kelas IX-A SMP Negeri 12 Tanjung Balai yang berjumlah 30 orang. Objek penelitian ini adalah tindakan sebagai upaya peningkatan motivasi dan hasil siswa dalam menyelesaikan permasalahan IPS pokok bahasan Kerja Sama Internasional metode Quantum teaching.

Desain penelitian yang dilaksanakan adalah desain yang menggunakan metode Mc.Taggart dalam Arikunto (2008:16) yang dikemukakan secara skematis seperti terlihat pada skema berikut ini. 


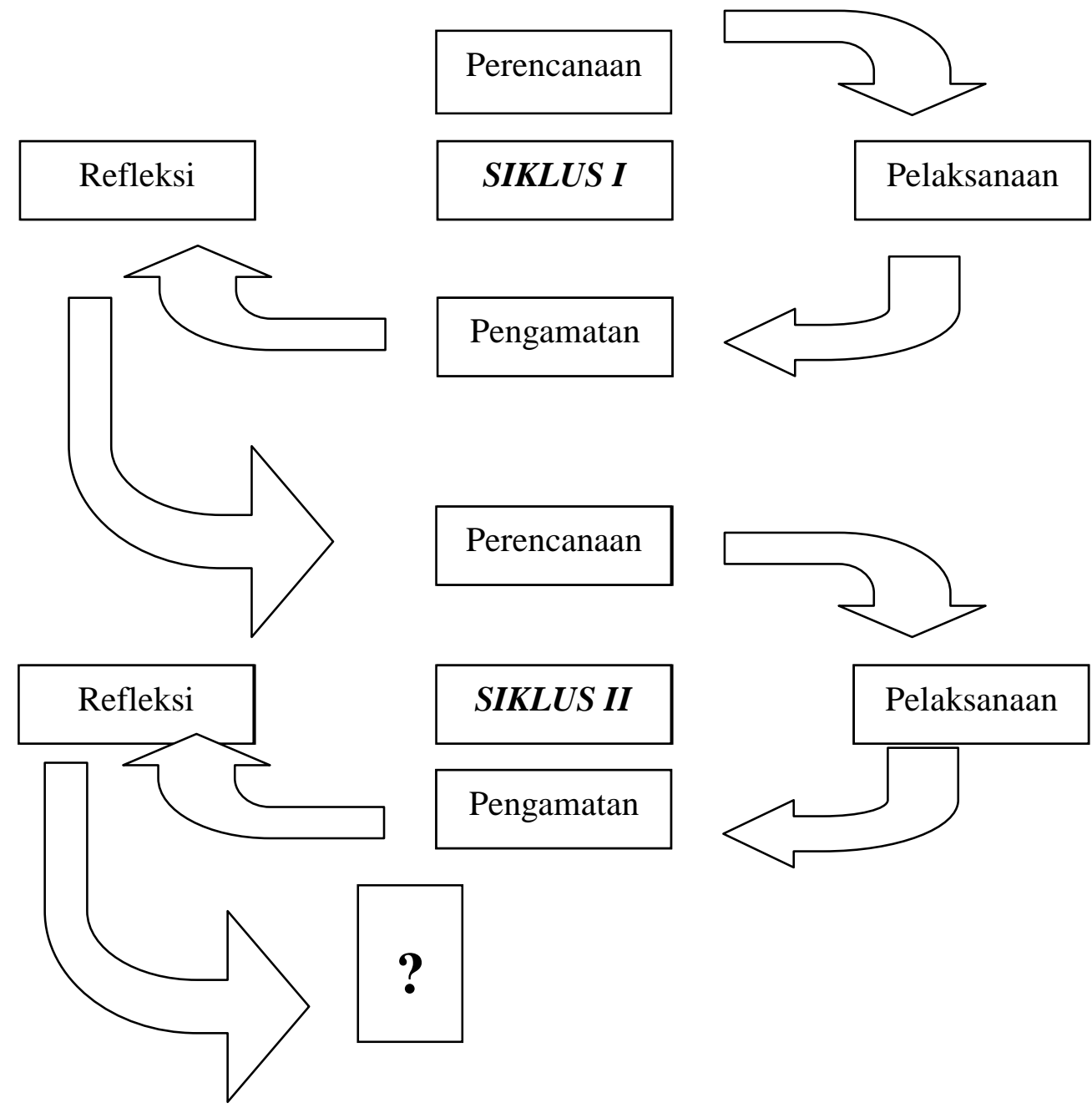

Gambar 1. Model desain penelitian tindakan kelas Mc.Taggart

Sesuai dengan jenis penelitian ini, yaitu penelitian tindakan kelas maka penelitian ini memiliki beberapa tahap pelaksanaan tindakan dengan siklus dimana setiap siklusnya mempunyai empat tahap yang akan dijelaskan sebagai berikut:

\section{Siklus I}

\section{Tahap Perencanaan}

Kegiatan yang dilakukan dalam perencanaan adalah:

1. Menyusun rencana pelaksanaan pembelajaran untuk setiap pertemuan dengan penggunaan metode Quantum teaching.

2. Menyediakan media pembelajaran.

3. Menyusun indikator motivasi untuk mengetahui motivasi belajar siswa selama tindakan penelitian.

4. Menyusun indikator kemampuan peneliti menerapkan RPP.

\section{Tahap Pelaksanaan Tindakan}

Kegiatan yang dilaksanakan dalam tahap ini adalah melaksanakan tindakan sesuai dengan yang telah direncanakan, berupa proses pembelajaran sesuai dengan rencana peleksanaan pembelajaran. 
Tahap pelaksanaan tindakan sebagai berikut:

1. Peneliti memeriksa kesiapan siswa untuk belajar

2. Menumbuhkan minat belajar siswa/memotivasi siswa dengan cara menunjukkan gambar yang berkaitan dengan materi sehingga akan menumbuhkan motivasi siwa dalam belajar. (Tumbuhkan)

3. Menyapaikan tujuan pembelajaran.

4. Menjelaskan kepada siswa tentang materi pelajaran dengan memberikan beberapa contoh yang berkaitan dengan kehidupan sehari-hari. Strategi yang digunakan pada pembelajaran ini yaitu meminta siswa mendengar dan mencatat materi (Kerja Sama Internasional) yang telah dijelaskan guru serta menjawab secara lisan pertanyaan yang diberikan oleh guru.

5. Peneliti membagi siswa menjadi beberapa kelompok untuk mempraktekkan contoh kegiatan yang ada Kerja Sama Internasional. (Alami)

6. Peneliti menyediakan kata kunci yang berfungsi sebagai masukan untuk siswa agar siswa mengerti apa yang telah dipelajari. Kemudian meminta siswa untuk menuliskan kegiatan yang telah dipraktekkan yaitu kegiatan Kerja Sama Internasional. (Namai)

7. Peneliti dan siswa bekerja sama mendemonstrasikan suatu konsep yang berkaitan dengan materi atau peneliti membantu siswa untuk mengembangkan bersama untuk menuntut peragaan yang sesuai dengan kemampuan siswa. (Demonstrasi)

8. Memberikan tes kepada siswa tentang materi Kerja Sama Internasional.

9. Membimbing siswa dalam mengerjakan tes

10. Peneliti menunjukkan kepada siswa mengenai cara-cara mengulangi materi pelajaran yaitu dengan menyimpulkan materi dari awal hingga akhir dengan melakukan tanya jawab antara guru dengan siswa.

11. Peneliti memberikan kesempatan kepada siswa untuk menyimpulkan tentang materi yang di ajarkan. (Ulangi)

12. Peneliti dan siswa merayakan apa yang telah mereka pelajari dengan cara yang paling sesuai untuk merayakan, yaitu dengan meminta siswa bernyanyi secara bersama-sama. (Rayakan)

\section{Tahap Pengamatan}

Melaksanakan observasi terhadap pelaksanaan tindakan secara khusus dan proses pembelajaran secara umum dengan menggunakan lembar observasi yang telah disiapkan. Observasi yang dilakukan selama pembelajarn berlangsung dibantu oleh guru kelas menyangkut keaktifan belajar siswa dalam mengikuti pelajaran.Pengamatan ini bertujuan untuk kesesuaian tindakan dengan rencana yang telah disusun dan guru mengetahui sejauh mana pelaksanaan tindakan dapat menghasilkan perubahan sesuai dengan yang dikehendaki.

- Alat pemantau yang dipergunakan dalam penelitian ini yaitu lembar observasi, untuk pelaksanaan pembelajaran dengan metode Quantum teaching dan untuk mengamati motivasi belajar siswa.

Lembar observasi yang digunakan untuk melihat motivasi belajar terhadap pembelajaran IPS, menurut Sardiman (2003:12) mengemukakan ciri-ciri motivasi yaitu: 
1) tekun menghadapi tugas.2) ulet menghadapi kesulitan.3) menunjukkan minat terhadap bermacam-macam masalah.4) lebih senang bekerja mandiri.5) dapat mempertahankan pendapatnya.6) bekerja sama dalam mencari dan memecahkan masalah soal-soal.

\section{Tahap Refleksi}

Kegiatan refleksi ini merupakan pedoman mengajar yang dilakukan serta melihat kesesuaian yang dicapai dengan keinginan dalam pembelajaran IPS, dimana dari hasil observasi yang dilakukan diberi kesempatan untuk menilai "Apakah dengan penerapan metode Quantum teaching pembelajaran sudah berjalan secara optimal?" Dan apakah siswa sudah termotivasi dalam pembelajaran kerjasama internasional. Jika masih banyak siswa yang masih mengalami kesulitan dalam pembelajaran tersebut maka perlu dipelajari kelemahan/kekurangan yang akan dihadapi untuk memperbaiki pelaksanaannya dan peneliti harus merencanakan lagi tahap tindakan ke 2 pada siklus II dengan tahap yang sama. Dan hasil refleksi ini digunakan pula sebagai dasar untuk tahap perencanaan pada siklus yang berikutnya.

Setelah melakukan pembelajaran dengan penerapan metode Quantum teaching selama 2 kali pertemuan, maka dapat dilaksanakan evaluasi untuk mengukur seberapa besar tingkat keberhasilan siswa dari tindakan yang telah dilakukan. Evaluasi yang dilakukan peneliti dengan menggunakan tes pilihan berganda dan dilakukan pada setiap akhir siklus.

\section{Siklus II}

\section{Tahap Perencanaan}

Prosedur ini sama dengan siklus I, tahap pembelajaran ini dilakukan untuk memperbaiki kekurangan pada siklus I. Dimana peneliti memfokuskan kesulitan yang dialami siswa.

Pada tahap ini perencanaan tindakan pada setiap siklus adalah:

1. Menyusun rencana pelaksanaan pembelajaran yang sesuai dengan materi dengan penggunaan metode Quantum teaching. Berdasarkan kekurangan atau kesalahan pada siklus I.

2. Menyediakan media pembelajaran.

3. Menyusun indikator motivasi untuk mengetahui motivasi belajar siswa selama tindakan penelitian.

\section{Tahap Pelaksanaan Tindakan}

Peneliti melakukan kegiatan yang sama pada siklus I, dilakukan setelah ada perbaikan. Dimana peneliti dan guru berusaha sebaik mungkin memberikan pengarahan dan bimbingan kepada siswa. Pada tahap ini proses belajar mengajar yang dilakukan selama 2 jam pelajaran dimana untuk melihat apakah siswa semakin menyerap pelajaran, paham, menguasai, aktif, kreatif dan mempunyai motivasi dalam proses belajar mengajar.

Pada hari berikutnya peneliti tetap menerapkan metode Quantum teaching, setelah selesai menerangkan peneliti tersebut memberikan tes (soal) untuk diselesaikan. Hal ini digunakan untuk melihat apakah siswa lebih termotivasi dan lebih menyerap materi pelajaran. Soal diberikan kepada setiap orang siswa agar dapat diketahui hasil belajar setiap orang siswa.

Pada tahap ini pelaksanaan tindakan ini adalah:

1. Peneliti mengadakan apersepsi siklus I 
2. Peneliti membahas materi yang dianggap sulit oleh siswa, sehingga siswa yang kurang memahami konsep materi tersebut akan semakin dimengerti.

3. Menyampaikan tujuan pembelajaran.

4. Menumbuhkan minat belajar siswa/memotivasi siswa dengan cara menunjukkan gambar yang berkaitan dengan materi sehingga akan menumbuhkan motivasi siwa dalam belajar. (Tumbuhkan)

5. Menjelaskan kepada siswa tentang materi pelajaran dengan memberikan beberapa contoh yang berkaitan dengan kehidupan sehari-hari. Strategi yang digunakan pada pembelajaran ini yaitu meminta siswa mendengar dan mencatat materi (Kerja Sama Internasional) yang telah dijelaskan guru serta menjawab secara lisan pertanyaan yang diberikan oleh guru.

6. Peneliti membagi siswa menjadi beberapa kelompok untuk mempraktekkan contoh kegiatan Kerja Sama Internasional. (Alami)

7. Peneliti menyediakan kata kunci yang berfungsi sebagai masukan untuk siswa agar siswa mengerti apa yang telah dipelajari. Kemudian meminta siswa menuliskan dipapan tulis tentang kegiatan yang telah dipraktekkan yaitu Kerja Sama Internasional. (Namai)

8. Peneliti dan siswa bekerja sama mendemonstrasikan suatu konsep yang berkaitan dengan materi atau peneliti membantu siswa untuk mengembangkan bersama untuk menuntut peragaan yang sesuai dengan kemampuan siswa. (Demonstrasi)

9. Memberikan tes kepada siswa tentang materi Kerja Sama Internasional.

10. Membimbing siswa dalam mengerjakan tes

11. Peneliti menunjukkan kepada siswa mengenai cara-cara mengulangi materi pelajaran yaitu dengan menyimpulkan materi dari awal hingga akhir dengan melakukan tanya jawab antara guru dengan siswa.

12. Peneliti memberikan kesempatan kepada siswa untuk memberikan kesimpulan tentang materi yang di ajarkan. (Ulangi)

13. Peneliti dan siswa merayakan apa yang telah mereka pelajari dengan cara yang paling sesuai untuk merayakan, yaitu dengan meminta siswa bernyayi secara bersama-sama. (Rayakan)

\section{Tahap Pengamatan}

Melaksanakan observasi terhadap pelaksanaan tindakan secara khusus dan proses pembelajaran secara umum dengan menggunakan lembar observasi yang telah disiapkan. Observasi yang dilakukan selama pembelajaran berlangsung dibantu oleh guru kelas menyangkut keaktifan belajar siswa dalam mengikuti pelajaran. Pengamatan ini bertujuan untuk kesesuaian tindakan dengan rencana yang telah disusun dan guru mengetahui sejauh mana pelaksanaan tindakan dapat menghasilkan perubahan sesuai dengan yang dikehendaki.

- Alat pemantau yang dipergunakan dalam penelitian ini yaitu lembar observasi, untuk pelaksanaan pembelajaran dengan metode Quantum teaching dan untuk mengamati motivasi belajar siswa.

\section{Tahap Refleksi}

Mengkaji berbagai hal yang terjadi dan seharusnya dilakukan refleksi terhadap tindakan yang sedang dan sesudah dilakukan. Setelah melakukan pembelajaran dengan penerapan metode Quantum teaching selama 2 kali pertemuan, maka dapat dilaksanakan evaluasi untuk mengukur seberapa besar tingkat keberhasilan siswa dari tindakan yang telah dilakukan. Evaluasi yang 
dilakukan peneliti dengan menggunakan tes essay dan dilakukan pada setiap akhir siklus. Alat yang digunakan dalam pengumpulan data pada penelitian ini adalah lembaran observasi, wawancara dan catatan lapangan.

Kriteria untuk menentukan peningkatan dari motivasi belajar siswa dapat dilihat menurut Arikunto (2007:44) sebagai berikut:

a. Sangat baik $\quad: 80 \%-100 \%$ dari jumlah siswa dari tiap indikator

b. Baik $\quad: 60 \%-79 \%$ dari jumlah siswa dari tiap indikator

c. Cukup $\quad: 40 \%-59 \%$ dari jumlah siswa dari tiap indikator

d. Kurang $\quad: 20 \%-39 \%$ dari jumlah siswa dari tiap indikator

e. Sangat kurang $: 0 \%-19 \%$ dari jumlah siswa dari tiap indikator

Untuk mengukur variabel motivasi belajar siswa, dilakukan dengan menggunakan perhitungan sebagai berikut:

$\mathrm{P}=\mathrm{f} / \mathrm{n} \times 100 \%$

Keterangan:

$\mathrm{P}$ : Angka motivasi belajar siswa

$\mathrm{f}$ : Jumlah siswa yang mengalami perubahan

$\mathrm{n}$ : Jumlah siswa keseluruhan

Analisa data yang dilakukan yaitu:

- Melakukan pemeriksaan data yang sudah masuk

- Melakukan penafsiran

- Menyimpulkan apakah tindakan pembelajaran ini terjadi peningkatan motivasi belajar siswa atau tidak berdasarkan observasi

- Tahap tindak lanjut yaitu merumuskan langkah-langkah perbaikan siklus berikutnya

- Pengambilan keputusan.

\section{HASIL PENELITIAN DAN PEMBAHASAN \\ Deskripsi Keadaan Awal}

Langkah pertama yang dilakukan oleh peneliti adalah melakukan identifikasi terhadap masalah yang akan diteliti dengan melakukan kegiatan pengamatan terhadap perilaku siswa.

Penelitian dilakukan pada saat siswa berada dikelas dengan menggunakan alat bantu berupa daftar checklist untuk melihat gejala motivasi belajar pada saat siswa belajar dikelas seperti perilaku belajar siswa yang diantaranya adalah tekun menghadapi tugas, ulet menghadapi kesulitan, menunjukkan minat yang tinggi, bekerja mandiri, dapat mempertahankan pendapat dan bagaimana mencari dan memecahkan masalah kelas yang diobservasi dengan menggunakan daftar checklist adalah siswa kelas Kelas IX-A SMP Negeri 12 dan berdasarkan daftar checklist dari setiap indikator yang telah ditetapkan hampir rata-rata siswa memiliki motivasi belajar yang sangat rendah, hal ini dapat dilihat berdasarkan hasil observasi yang dilakukan oleh peneliti dikelas Kelas IX-A SMP Negeri 12 bahwa sebagian besar siswa tidak suka atau tidak ada motivasi belajar pada mata pelajaran sains sehingga siswa mencari kesibukan yang lain untuk mengatasi kejenuhannya terhadap pelajaran tersebut.

Motivasi belajar yang rendah untuk melihat tiap indikator yang telah ditetapkan dapat dilihat melalui tes awal yang dilakukan pada awal kegiatan penelitian sebelum dilakukan kegiatan siklus I dan siklus II, setiap akhir dari siklus dilakukan maka diadakan tes evaluasi. 
Tabel 1. Tabel Observasi Kondisi Awal Motivasi Belajar Siswa

\begin{tabular}{|c|c|c|c|}
\hline No & Indikator Motivasi & Kondisi Awal & $\%$ \\
\hline 1 & $\begin{array}{l}\text { Tekun menghadapi tugas } \\
\text { a. Tidak cepat bosan } \\
\text { b. Perhatian konsentrasi pada saat guru } \\
\text { menjelaskan semakin tinggi } \\
\text { c. Niat yang tinggi untuk mengerjakan tugas }\end{array}$ & $\begin{array}{l}11 \\
10 \\
14\end{array}$ & $\begin{array}{l}36 \% \\
33 \% \\
46 \% \\
\end{array}$ \\
\hline 2. & $\begin{array}{l}\text { Ulet menghadapi kesulitan } \\
\text { a. Melakukan kegiatan belajar tanpa ada } \\
\text { paksaan dari luar } \\
\text { b. Memiliki motivasi berprestasi yang tinggi } \\
\text { c. Tidak cepat merasa puas dengan prestasi } \\
\text { yang dicapai } \\
\text { d. Giat dan rela untuk melakukan kegiatan } \\
\text { belajar }\end{array}$ & $\begin{array}{c}12 \\
10 \\
8 \\
11\end{array}$ & $\begin{array}{l}40 \% \\
33 \% \\
26 \% \\
36 \%\end{array}$ \\
\hline 3. & $\begin{array}{l}\text { Menunjukkan minat yang tinggi terhadap } \\
\text { bermacam-macam masalah } \\
\text { a. Disiplin dalam belajar } \\
\text { b. Keinginan memecahkan masalah } \\
\text { c. Mengerjakan tugas dengan tepat waktu }\end{array}$ & $\begin{array}{c}10 \\
5 \\
10\end{array}$ & $\begin{array}{l}33 \% \\
16 \% \\
33 \%\end{array}$ \\
\hline 4. & $\begin{array}{l}\text { Bekerja mandiri } \\
\text { a. Memiliki sikap kreatif } \\
\text { b. Berusaha menyelesaikan tugas-tugas } \\
\text { c. Bekerja sendiri dalam menerjakan tugas }\end{array}$ & $\begin{array}{c}6 \\
11 \\
10\end{array}$ & $\begin{array}{l}20 \% \\
36 \% \\
33 \% \\
\end{array}$ \\
\hline 5. & $\begin{array}{l}\text { Dapat mempertahankan pendapatnya } \\
\text { a. Berani mengemukakan pendapat } \\
\text { b. Suka bertanya terhadap yang tidak dipahami } \\
\text { c. Adanya sikap mengkritik } \\
\text { d. menyukai tugas yang sulit dan berat }\end{array}$ & $\begin{array}{l}10 \\
6 \\
8 \\
5\end{array}$ & $\begin{array}{l}33 \% \\
20 \% \\
26 \% \\
16 \%\end{array}$ \\
\hline 6. & $\begin{array}{l}\text { Bekerja sama dalam mencari dan memecahkan } \\
\text { masalah } \\
\text { a. Senang berdiskusi } \\
\text { b. Senang bekerja sama dengan teman } \\
\text { c. Senang bekerja sama dengan guru }\end{array}$ & $\begin{array}{l}14 \\
11 \\
11\end{array}$ & $\begin{array}{l}46 \% \\
36 \% \\
36 \%\end{array}$ \\
\hline
\end{tabular}

Dari data hasil observasi dapat diketahui bahwa motivasi belajar siswa kelas IX-A SMP Negeri 12 Tanjung Balai bisa dikatakan masih rendah, hal ini dapat kita lihat:

1. Hanya ada 3 indikator untuk kriteria cukup atau sebesar $15 \%$ dari 20 indikator yang ada.

2. Ada 14 indikator untuk kriteria kurang atau sebesar $70 \%$ dari 20 indikator yang ada.

3. Ada 3 indikator untuk kriteria yang sangat kurang atau sebesar $15 \%$ dari 20 indikator yang ada.

Melihat dari data diatas peneliti mengadakan diskusi dengan guru kelas untuk mengawasi apa yang menjadi penyebab rendahnya motivasi belajar siswa. Peneliti mengadakan catatan untuk menganalisis data tersebut dengan 
mengadakan pembelajaran dengan menggunakan metode Quantum teaching untuk meningkatkan motivasi belajar siswa.

\section{Deskripsi Siklus I}

a. Tahap perencanaan

1. Melakukan observasi awal untuk menentukan model dan format penerapan tindakan kelas pada siklus I.

2. Membuat Rencana Pelaksanaan Pembelajaran (RPP) untuk setiap pertemuan dengan menggunakan metode Quantum teaching.

3. Menyusun daftar checklist untuk mengetahui motivasi belajar siswa selama tindakan.

4. Membuat daftar catatan lapangan untuk mencatat semua kegiatan yang ada pada saat penelitian.

b. Pelaksanaan Tindakan

Pada kegiatan ini tindakan peneliti bersama guru kelas dengan menggunakan metode Quantum teaching yang bertujuan untuk meningkatkan motivasi belajar siswa khususnya pada pelajaran IPS.

Selain itu peneliti juga menggunakan teori-teori dari metode Quantum teaching yang bertujuan untuk mengembangkan kebiasaan yang baik dalam pembelajaran siswa. Penggunaan konsep metode Quantum teaching yang bertujuan untuk menyadari akan kemampuan, pengalaman dalam belajar, serta situasi yang dimiliki siswa dalam pemakaian dari metode Quantum teaching yang bertujuan untuk membuat siswa menerima dan berani memikul tanggung jawab atas pekerjaannya.

Selain itu peneliti juga menggunakan bahasa positif (memberi penguatan) kepada siswa seperti “ya, bagus sekali". Pemberian bahasa positif ini diharapkan agar siswa lebih merasa dihargai atas usahanya dalam mengrjakan sesuatu dan pemberian bahasa positif ini diterapkan untuk dapat meningkatkan motivasi belajar siswa.

Kegiatan yang dilakukan untuk meningkatkan motivasi belajar siswa dalam proses pembelajaran adalah:

1. Peneliti memeriksa kesiapan siswa

2. Menyampaikan tujuan pembelajaran yang harus dicapai

3. Memotivasi siswa untuk lebih tekun belajar

4. Menjelaskan materi pelajaran kepada siswa dengan memberikan beberapa contoh

5. Membagi siswa menjadi 3 kelompok

6. Membimbing dan mengawasi siswa dalam pelaksanaan tugas yaitu mempraktekkan kegiatan di kerja sama internasional sekolah

7. Meminta siswa menuliskan konsep yang telah di praktekkan

8. Meminta siswa mendemonstrasikan konsep yang telah dipelajari

9. Membimbing siswa dalam menyimpulkan materi

10. Memberi tugas kepada siswa dalam bentuk essay

11. Bernyanyi bersama untuk merayakan apa yang telah dipelajari

c. Pengamatan atau Observasi

Pada tahap ini guru kelas sebagai pengamat (observer) melakukan observasi dikelas IX-A dengan menggunakan daftar checklist. Tahap pelaksanaan kegiatan pembelajaran yang menerapkan bimbingan belajar dengan menggunakan 
metode Quantum teaching. Selanjutnya hasil observasi dengan alat bantu daftar checklist dapat dilihat pada tabel 4.2 :

Selama observasi banyak hal yang diperoleh antara lain:

1. Pada awal kegiatan ini siswa memiliki respon yang sangat baik terhadap kehadiran peneliti yang akan meneliti kegiatan mereka.

2. Pada siklus ini masih banyak siswa yang belum menunjukkan niat yang tinggi untuk mengerjakan tugas.

3. Pada tahap ini masih banyak siswa yang belum memiliki motivasi belajar yang tinggi.

d. Refleksi

Berdasarkan hasil observasi pada siklus I, maka peneliti melakukan refleksi terhadap seluruh kegiatan pada siklus I.

1. Hanya sebagian siswa yang mau berpartisipasi memikirkan pemecahan masalah tentang konsep pelajaran yang dipelajari.

2. Sebagian besar siswa bingung mengikuti proses pembelajaran dengan penerapan metode Quanutm teaching.

3. Sebagian siswa sukar mengemukakan pendapatnya, siswa masih cenderung diam.

4. Hanya sebagian kecil siswa yang berusaha menyelesaikan tugas-tugasnya sesuai langkah-langkah pembelajaran yang telah ditetapkan.

Tabel 2. Tabel Hasil Observasi Siklus I

\begin{tabular}{|c|c|c|c|}
\hline No & Indikator Motivasi & $\begin{array}{l}\text { Jumlah siswa } \\
\text { yang } \\
\text { mengalami } \\
\text { perubahan }\end{array}$ & $\%$ \\
\hline 1 & $\begin{array}{l}\text { Tekun menghadapi tugas } \\
\text { a. Tidak cepat bosan } \\
\text { b. Perhatian konsentrasi pada saat guru } \\
\text { menjelaskan semakin tinggi } \\
\text { c. Niat yang tinggi untuk mengerjakan tugas }\end{array}$ & $\begin{array}{l}21 \\
14 \\
15\end{array}$ & $\begin{array}{l}70 \% \\
46 \% \\
50 \%\end{array}$ \\
\hline 2. & $\begin{array}{l}\text { Ulet menghadapi kesulitan } \\
\text { a. Melakukan kegiatan belajar tanpa ada } \\
\text { paksaan dari luar } \\
\text { b. Memiliki motivasi berprestasi yang tinggi } \\
\text { c. Tidak cepat merasa puas dengan prestasi } \\
\text { yang dicapai } \\
\text { d. Giat dan rela untuk melakukan kegiatan } \\
\text { belajar }\end{array}$ & $\begin{array}{l}20 \\
11 \\
11 \\
19\end{array}$ & $\begin{array}{l}66 \% \\
36 \% \\
36 \% \\
63 \%\end{array}$ \\
\hline 3. & $\begin{array}{l}\text { Menunjukkan minat yang tinggi terhadap } \\
\text { bermacam-macam masalah } \\
\text { a. Disiplin dalam belajar } \\
\text { b. Keinginan memecahkan masalah } \\
\text { c. Mengerjakan tugas dengan tepat waktu }\end{array}$ & $\begin{array}{l}14 \\
20 \\
21\end{array}$ & $\begin{array}{l}46 \% \\
66 \% \\
70 \% \\
\end{array}$ \\
\hline 4. & $\begin{array}{l}\text { Bekerja mandiri } \\
\text { a. Memiliki sikap kreatif } \\
\text { b. Berusaha menyelesaikan tugas-tugas } \\
\text { c. Bekerja sendiri dalam mengerjakan tugas }\end{array}$ & $\begin{array}{l}10 \\
14 \\
13\end{array}$ & $\begin{array}{l}33 \% \\
46 \% \\
43 \%\end{array}$ \\
\hline 5. & Dapat mempertahankan pendapatnya & & \\
\hline
\end{tabular}




\begin{tabular}{|l|l|l|l|}
\hline & a. Berani mengemukakan pendapat & 11 & $36 \%$ \\
b. Suka bertanya terhadap yang tidak dipahami & 14 & $46 \%$ \\
& c. Adanya sikap mengkritik & 10 & $33 \%$ \\
d. menyukai tugas yang sulit dan berat & 13 & $43 \%$ \\
\hline 6. & & \\
& Bekerja sama dalam mencari dan memecahkan & & \\
masalah & 21 & $70 \%$ \\
a. Senang berdiskusi & 15 & $50 \%$ \\
b. Senang bekerja sama dengan teman & 17 & $56 \%$ \\
\hline
\end{tabular}

Dari hasil observasi pada siklus I diatas dapat diketahui bahwa motivasi belajar siswa kelas IX-A masih tergolong rendah, hal ini dapat dilihat dari :

1. Ada 6 indikator yang masuk kriteria baik, atau sebesar $30 \%$ dari 20 indikator yang ada. Jumlah indikator mengalami peningkatan pada kriteria ini dari awal kegiatan observasi setelah dilakukan tindakan. Jumlah siswa mengalami perubahan cukup meningkat yaitu menjadi 21 orang siswa atau naik sekitar $34 \%$ untuk indikator tidak cepat bosan menghadapi tugas, 20 orang siswa atau naik sekitar 26\% untuk indikator melakukan kegiatan belajar tanpa ada paksaan dari luar, 19 orang siswa atau naik sekitar $27 \%$ untuk indikator giat dan rela untuk melakukan kegiatan belajar, 20 orang siswa atau naik sekitar $50 \%$ untuk indikator keinginan memecahkan masalah, 21 orang siswa atau naik sekitar $37 \%$ untuk indikator mengerjakan tugas tepat waktu, 21 orang siswa atau naik sekitar $24 \%$ untuk indikator senang berdiskusi.

2. Ada 9 indikator yang masuk kriteria cukup atau sebesar $45 \%$ dari 20 indikator yang ada. Jumlah indikator mengalami peningkatan pada kriteria ini dari awal kegiatan observasi sebelum dilakukan tindakan dari yang sebelumnya tidak ada menjadi ada. Dengan jumlah siswa yang mengalami perubahan yaitu 14 orang siswa atau naik sekitar $13 \%$ untuk indikator perhatian konsentrasi pada saat guru menjelaskan semakin tinggi, 15 orang siswa atau naik sekitar $4 \%$ untuk indikator niat yang tinggi untuk mengerjakan tugas, 14 orang siswa atau naik sekitar 13\% untuk indikator disiplin dalam belajar, 14 orang siswa atau naik sekitar $10 \%$ untuk indikator berusaha menyelesaikan tugas-tugas, 13 orang siswa atau naik sekitar $23 \%$ untuk indikator bekerja sendiri dalam mengerjakan tugas, 14 orang siswa atau naik sekitar $26 \%$ untuk indikator suka bertanya terhadap yang tidak dipahami, 13 orang siswa atau naik sekitar $27 \%$ untuk indikator menyukai tugas yang sulit dan berat, 15 orang siswa atau naik sekitar 14\% untuk indikator senang bekerja sama dengan teman, 17 orang siswa atau naik sekitar 20\% untuk indikator dapat bekerjasama dengan guru.

3. Ada 5 indikator untuk kriteria kurang atau sebesar $25 \%$ dari indicator yang ada. Jumlah indikator mengalami peningkatan pada kriteria dari awal kegiatan observasi sebelum dilakukan tindakan. Dengan jumlah siswa yang mengalami peningkatan menjadi 11 orang siswa atau naik sekitar 3\% untuk indikator memiliki motivasi berprestasi yang tinggi, 11 orang siswa atau naik sekitar $10 \%$ untuk indikator tidak cepat merasa puas dengan prestasi yang dicapai, 10 orang siswa atau naik sekitar $13 \%$ untuk indikator memiliki sikap kreatif, 11 orang siswa atau naik sekitar 3\% untuk indikator berani mengemukakan pendapat, dan 10 orang siswa atau naik sekitar $7 \%$ untuk indikator adanya sikap mengkritik. 
Berdasarkan hal diatas maka peneliti mencari faktor penghambat dan pendukung dari pelaksanaan kegiatan ini, dan ditemukan hasil sebagai berikut.

a. Faktor penghambat

1. Kurang siapnya siswa dalam menghadapi situasi yang baru dilakukan oleh peneliti.

2. Belum siapnya siswa untuk melakukan suatu tindakan tanpa diminta oleh peneliti.

3. Ada beberapa siswa yang masih belum siap menghadapi perubahan dalam gaya mengajar.

b. Faktor pendukung

Banyak siswa yang senang dalam mengikuti pelajaran.

\section{Deskripsi Siklus II}

a. Tahap-tahap perencanaan

1. Melakukan observasi lanjutan untuk menemukan format penerapan tindakan siklus II.

2. Menyusun rencana pelaksanaan pembelajaran dengan menggunakan metode Quantum teaching. Dengan berpedoman kepada kekurangan pada siklus I.

3. Menyusun daftar checklist untuk mengetahui tinggi rendahnya motivasi belajar siswa selama tindakan penelitian diterapkan.

b. Pelaksanaan tindakan

Pada pelaksanaan tindakan siklus II ini, guru tetap menerapkan bimbingan dengan menggunakan metode Quantum teaching. Hal ini bertujuan agar siswa lebih semangat lagi untuk mengikuti pelajaran dan kegiatan belajar bisa lebih kondusif lagi karena dari hasil refleksi dan evaluasi pada siklus I, dapat disimpulkan bahwa kegiatan pembelajaran belum benar-benar kondusif. Karena peneliti belum siap menghadapi situasi yang baru dan siswa belum siap menghadapi perubahan yang terjadi dalam kegiatan pembelajaran, misalnya belum siapnya siswa untuk maju kedepan kelas untuk mengerjakan tugas yang diberikan oleh peneliti, belum siapnya siswa mutnuk mengemukakan pendapat, belum siapnya siswa mengejakan sesuatu tugas tanpa ada perintah dari peneliti.

Pada tahap ini kegiatan yang dilakukan peneliti adalah sama dengan siklus I hal ini dikarenakan berdasarkan hasil observasi yang telah dilakukan banyak siswa yang senang dalam mengikuti kegiatan pembelajaran yang diterapkan oleh peneliti.

Kegiatan yang dilakukan untuk mengingkatkan motivasi belajar dalam bentuk metode Quantum teaching adalah sebagai berikut:

1. Peneliti membahas materi yang dianggap sulit oleh siswa, sehingga siswa yang kurang memahami konsep materi tersebut akan semakin dimengerti.

2. Menjelaskan materi pelajaran kepada siswa dengan memberikan beberapa contoh.

3. Membagi siswa menjadi 3 kelompok.

4. Membimbing dan mengawasi siswa dalam pelaksanaan tugas yaitu mempraktekkan kegiatan di kerjasama internasional sekolah.

5. Meminta siswa menuliskan konsep yang telah di praktekkan.

6. Meminta siswa mendemonstrasikan konsep yang telah dipelajari. 
7. Membimbing siswa dalam menyimpulkan materi.

8. Memberi tugas kepada siswa dalam bentuk essay.

9. Bernyanyi bersama untuk merayakan apa yang telah dipelajari.

c. Pengamatan atau observasi

Pada tahap ini peneliti bersama guru kelas melaksanakan observasi dengan menggunakan alat Bantu daftar checklist terhadap pelaksanaan kegiatan pembelajaran dengan menggunakan metode Quantum teaching. Berdasakan hasil observasi yang telah dilakukan oleh peneliti bersana dengan guru kelas diperoleh hasil bahwa semua indikator dari motivasi telah mengalami peningkatan.

d. Refleksi

1. Semakin banyak siswa yang sudah dapat mencari dan memecahkan soal-aoal yang diberikan oleh peneliti.

2. Sebagian besar siswa tekun dalam menghadapi tugas hal ini dapat dilihat dari siswa yang tidak cepat bosan dalam kegiatan belajar, perhatian konsentrasi pada saat peneliti menjelaskan yang ditunjukkan dengan keseriusan siswa dalam menyelesaikan tugas.

3. Sebagian besar siswa yang mengemukakan tanggapan ketika belajar melalui metode Quantum teaching.

4. Semakin besarnya jumlah siswa yang memiliki rasa ingin tahu terhadap materi pelajaran yang dibahas.

5. Hampir semua siswa memiliki keinginan untuk memecahkan persoalan yang dilihat dari kegiatan belajar dengan menggunakan metode Quantum teaching.

Tabel 3. Tabel Hasil Observasi Siklus II

\begin{tabular}{|c|c|c|c|}
\hline No & Indikator Motivasi & $\begin{array}{c}\text { Jumlah siswa } \\
\text { yang } \\
\text { mengalami } \\
\text { perubahan }\end{array}$ & $\%$ \\
\hline 1 & $\begin{array}{l}\text { Tekun menghadapi tugas } \\
\text { a. Tidak cepat bosan } \\
\text { b. Perhatian konsentrasi pada saat guru } \\
\text { menjelaskan semakin tinggi } \\
\text { c. Niat yang tinggi untuk mengerjakan tugas }\end{array}$ & $\begin{array}{l}26 \\
22 \\
\\
25 \\
\end{array}$ & $\begin{array}{l}86 \% \\
73 \% \\
83 \% \\
\end{array}$ \\
\hline 2. & $\begin{array}{l}\text { Ulet menghadapi kesulitan } \\
\text { a. Melakukan kegiatan belajar tanpa ada } \\
\text { paksaan dari luar } \\
\text { b. Memiliki motivasi berprestasi yang tinggi } \\
\text { c. Tidak cepat merasa puas dengan prestasi } \\
\quad \text { yang dicapai } \\
\text { d. Giat dan rela untuk melakukan kegiatan } \\
\text { belajar }\end{array}$ & $\begin{array}{l}22 \\
21 \\
20 \\
26\end{array}$ & $\begin{array}{l}73 \% \\
70 \% \\
66 \% \\
86 \%\end{array}$ \\
\hline 3. & $\begin{array}{l}\text { Menunjukkan minat yang tinggi terhadap } \\
\text { bermacam-macam masalah } \\
\text { a. Disiplin dalam belajar } \\
\text { b. Keinginan memecahkan masalah } \\
\text { c. Mengerjakan tugas dengan tepat waktu }\end{array}$ & $\begin{array}{l}25 \\
22 \\
28\end{array}$ & $\begin{array}{l}83 \% \\
73 \% \\
93 \%\end{array}$ \\
\hline 4. & $\begin{array}{l}\text { Bekerja mandiri } \\
\text { a. Memiliki sikap kreatif }\end{array}$ & 20 & $66 \%$ \\
\hline
\end{tabular}




\begin{tabular}{|c|l|c|c|}
\hline & b. Berusaha menyelesaikan tugas-tugas & 23 & $76 \%$ \\
& c. Bekerja sendiri dalam mengerjakan tugas & 21 & $70 \%$ \\
\hline 5. & Dapat mempertahankan pendapatnya & & \\
& a. Berani mengemukakan pendapat & 22 & $73 \%$ \\
& b. Suka bertanya terhadap yang tidak dipahami & 21 & $70 \%$ \\
& c. Adanya sikap mengkritik & 20 & $66 \%$ \\
& d. menyukai tugas yang sulit dan berat & 20 & $66 \%$ \\
\hline \multirow{6}{*}{ Bekerja sama dalam mencari dan memecahkan } & & \\
& masalah & 27 & $90 \%$ \\
& a. Senang berdiskusi & 27 & $90 \%$ \\
b. Senang bekerja sama dengan teman & 28 & $93 \%$ \\
\hline
\end{tabular}

Dari data hasil observasi pada siklus II dapatlah diketahui bahwa motivasi belajar siswa kelas IX-A bisa dikatakan meningkat, hal ini terlihat dari:

1. Ada 12 indikator yang termasuk kriteria sangat baik atau sebesar $60 \%$ dari 20 indikator yang ada. Jumlah indikator yang mengalami peningkatan pada kriteria awal kegiatan observasi setelah dilakukan tindakan. Jumlah siswa yang mengalami perubahan cukup meningkat dari setelah tindakan yaitu menjadi 26 orang siswa atau naik sekitar $16 \%$ untuk indikator tidak cepat bosan ,25 orang siswa atau naik sekitar $37 \%$ untuk indikator perhatian pada saat guru menjelaskan semakin tinggi, 25 orang siswa atau naik sekitar $33 \%$ untuk indikator niat yang tinggi untuk mengerjakan tugas, 26 orang siswa atau naik sekitar $20 \%$ untuk indikator melakukan kegiatan belajar tanpa ada paksaan dari luar, 26 orang siswa atau naik sekitar $23 \%$ untuk indikator giat dan rela untuk melakukan kegiatan belajar, 25 orang siswa atau naik sekitar $37 \%$ untuk indikator disiplin dalam belajar, 28 orang siswa atau naik sekitar $23 \%$ untuk indikator mengerjakan tugas tepat waktu, 26 orang siswa atau nauik sekitar $40 \%$ untuk indikator berusaha menyelesaikan tugas-tugas, 25 orang siswa atau naik sekitar $40 \%$ untuk indicator bekerja sendiri dalam mengerjakan tugas, 27 orang siswa atau naik sekitar $20 \%$ untuk indikator senang berdiskusi, 27 orang siswa atau naik sekitar $40 \%$ untuk indikator senang bekerja sama dengan teman, dan 28 orang siswa atau naik sekitar $37 \%$ untuk indikator senang bekerja sama dengan guru.

2. Ada 8 indikator yang masuk kriteria baik, atau sebesar $40 \%$ dari 20 indikator yang ada. Jumlah indikator mengalami peningkatan pada kriteria ini dari awal kegiatan observasi sebelum dilakukan tindakan. Jumlah siswa yang mengalami perubahan cukup meningkat setelah tindakan menjadi 21 orang siswa atau naik sekitar $34 \%$ untuk indikator memiliki motivasi berprestasi yang tinggi, 20 orang siswa atau naik sekitar $30 \%$ untuk indikator tidak cepat merasa puas dengan prestasi yang dicapai, 22 orang siswa atau naik sekitar $7 \%$ untuk indicator keinginan memecahkan masalah, 20 orang siswa atau naik sekitar 33\% untuk indikator memiliki sikap kreatif, 22 orang siswa atau naik sekitar $37 \%$ untuk indikator berani mengemukakan pendapat, 21 orang siswa atau naik sekitar $24 \%$ untuk indikator suka bertanya terhadap yang tidak dipahami, 20 orang siswa atau naik sekitar 33\% untuk indikator adanya sikap mengkritik, 20 orang siswa atau naik sekitar $23 \%$ untuk indikator menyukai tugas yang sulit dan berat. 


\section{Pembahasan Hasil Peningkatan Motivasi Belajar}

Berdasarkan hasil penelitian pada siklus I dan siklus II yang telah dilakukan oleh peneliti, maka terjadi perubahan yang dilihat selama penelitian yang dapat dilihat pada tabel berikut :

Tabel 4. Hasil Keseluruhan Observasi

\begin{tabular}{|c|c|c|c|c|c|c|c|}
\hline No & Indikator Motivasi & $\begin{array}{c}\text { Kondisi } \\
\text { Awal }\end{array}$ & $\%$ & $\begin{array}{l}\text { Jumlah } \\
\text { siswa yang } \\
\text { mengalami } \\
\text { perubahan }\end{array}$ & $\%$ & $\begin{array}{c}\text { Jumlah } \\
\text { siswa yang } \\
\text { mengalami } \\
\text { perubahan }\end{array}$ & $\%$ \\
\hline 1. & $\begin{array}{l}\text { Tekun menghadapi tugas } \\
\text { a. Tidak cepat bosan } \\
\text { b. Perhatian konsentrasi } \\
\text { saat guru menjelaskan } \\
\text { semakin tinggi } \\
\text { c. Niat yang tinggi untuk } \\
\text { mengerjakan tugas }\end{array}$ & $\begin{array}{l}11 \\
10\end{array}$ & $\begin{array}{l}36 \% \\
33 \% \\
46 \%\end{array}$ & $\begin{array}{l}21 \\
14\end{array}$ & $\begin{array}{l}70 \% \\
46 \% \\
50 \%\end{array}$ & $\begin{array}{l}26 \\
25\end{array}$ & $\begin{array}{l}86 \% \\
83 \% \\
83 \%\end{array}$ \\
\hline 2. & $\begin{array}{l}\text { Ulet menghadapi kesulitan } \\
\text { a. Melakukan kegiatan } \\
\text { belajar tanpa ada } \\
\text { paksaan dari luar } \\
\text { b. Memiliki motivasi } \\
\text { berprestasi yang tinggi } \\
\text { c. Tidak cepat merasa puas } \\
\text { dengan prestasi yang } \\
\text { dicapai } \\
\text { d. Giat dan rela untuk } \\
\text { melakukan kegiatan } \\
\text { belajar }\end{array}$ & $\begin{array}{l}10 \\
8\end{array}$ & $\begin{array}{l}40 \% \\
33 \% \\
26 \% \\
36 \%\end{array}$ & $\begin{array}{l}11 \\
11\end{array}$ & $\begin{array}{l}66 \% \\
36 \% \\
36 \% \\
63 \%\end{array}$ & $\begin{array}{l}21 \\
20\end{array}$ & $\begin{array}{l}86 \% \\
70 \% \\
66 \% \\
86 \%\end{array}$ \\
\hline 3. & $\begin{array}{l}\text { Menunjukkan minat yang } \\
\text { tinggi terhadap bermacam- } \\
\text { macam masalah } \\
\text { a. Displin dalam belajar } \\
\text { b. Keinginan memecahkan } \\
\text { masalah } \\
\text { c. Mengerjakan tugas tepat } \\
\quad \text { waktu }\end{array}$ & $\begin{array}{l}10 \\
5 \\
10\end{array}$ & $\begin{array}{l}33 \% \\
16 \% \\
33 \%\end{array}$ & $\begin{array}{l}14 \\
20 \\
21\end{array}$ & $\begin{array}{l}46 \% \\
66 \% \\
70 \%\end{array}$ & $\begin{array}{l}25 \\
22 \\
28\end{array}$ & $\begin{array}{l}83 \% \\
73 \% \\
93 \%\end{array}$ \\
\hline 4. & $\begin{array}{l}\text { Bekerja mandiri } \\
\text { a. Memiliki sikap kreatif } \\
\text { b. Berusaha menyelesaikan } \\
\quad \text { tugas-tugas } \\
\text { c. Bekerja sendiri dalam } \\
\text { mengerjakan tugas }\end{array}$ & $\begin{array}{c}6 \\
11 \\
10\end{array}$ & $\begin{array}{l}20 \% \\
36 \% \\
33 \%\end{array}$ & $\begin{array}{l}10 \\
14 \\
13\end{array}$ & $\begin{array}{l}33 \% \\
46 \% \\
43 \%\end{array}$ & $\begin{array}{l}20 \\
26 \\
25\end{array}$ & $\begin{array}{l}66 \% \\
86 \% \\
83 \%\end{array}$ \\
\hline 5. & $\begin{array}{l}\text { Dapat mempertahankan } \\
\text { pendapatnya } \\
\text { a. Berani mengemukakan }\end{array}$ & 10 & $33 \%$ & 11 & $36 \%$ & 22 & $73 \%$ \\
\hline
\end{tabular}




\begin{tabular}{|c|c|c|c|c|c|c|c|}
\hline & $\begin{array}{l}\text { pendapat } \\
\text { b. Suka bertanya terhadap } \\
\text { yang tidak dipahami } \\
\text { c. Adanya sikap } \\
\text { mengkritik } \\
\text { d. Menyukai tugas yang } \\
\text { sulit dan berat }\end{array}$ & $\begin{array}{l}6 \\
8 \\
5\end{array}$ & $\begin{array}{l}20 \% \\
26 \% \\
16 \%\end{array}$ & 13 & $\begin{array}{l}46 \% \\
33 \% \\
43 \%\end{array}$ & $\begin{array}{l}21 \\
20\end{array}$ & $\begin{array}{l}70 \% \\
66 \% \\
66 \%\end{array}$ \\
\hline 6. & $\begin{array}{l}\text { Bekerja sama dalam } \\
\text { mencari dan memecahkan } \\
\text { masalah } \\
\text { a. Senang berdiskusi } \\
\text { b. Senang bekerja sama } \\
\text { dengan teman } \\
\text { c. Senang bekerja sama } \\
\text { dengan guru }\end{array}$ & $\begin{array}{l}14 \\
11\end{array}$ & $\begin{array}{l}46 \% \\
36 \% \\
36 \%\end{array}$ & $\begin{array}{l}21 \\
15\end{array}$ & $\begin{array}{l}70 \% \\
50 \% \\
56 \%\end{array}$ & $\begin{array}{l}27 \\
27\end{array}$ & $\begin{array}{l}90 \% \\
90 \% \\
93 \%\end{array}$ \\
\hline
\end{tabular}

Dari data hasil observasi diatas dapat dilihat bahwa motivasi belajar siswa tersebut mengalami peningkatan yang cukup baik pada setiap indikator, ke 6 indikator motivasi belajar siswa dilihat dari hasil persentase yaitu:

Tabel 5. Tabel Indikator Motivasi Belajar Siswa

\begin{tabular}{|c|l|c|c|c|}
\hline No. & \multicolumn{1}{|c|}{ Indikator Motivasi } & Kondisi Awal & Siklus I & Siklus II \\
\hline 1. & Tekun menghadapi tugas & $38 \%$ & $55 \%$ & $84 \%$ \\
\hline 2. & Ulet menghadapi kesulitan & $33 \%$ & $50 \%$ & $77 \%$ \\
\hline 3. & $\begin{array}{l}\text { Menunjukkan minat yang } \\
\text { tinggi terhadap bermacam- } \\
\text { macam masalah }\end{array}$ & $38 \%$ & $60 \%$ & $83 \%$ \\
\hline 4. & Bekerja mandiri & $29 \%$ & $40 \%$ & $78 \%$ \\
\hline 5. & $\begin{array}{l}\text { Dapat mempertahankan } \\
\text { pendapatnya }\end{array}$ & $23 \%$ & $39 \%$ & $69 \%$ \\
\hline 6. & $\begin{array}{l}\text { Bekerja sama dalam } \\
\text { mencari dan memecahkan } \\
\text { masalah }\end{array}$ & $39 \%$ & $58 \%$ & $91 \%$ \\
\hline
\end{tabular}

Dari hasil observasi diatas bahwa semua kegiatan yang dilaksanakan dalam pembelajaran dengan menggunakan metode Quantum teaching mengalami perubahan yang baik. Dari keenam indikator motivasi belajar siswa mengalami perubahan yang sangat meningkat pada siklus II yaitu tekun menghadapi tugas $84 \%$, ulet menghadapi kesulitan $77 \%$, menunjukkan minat yang tinggi terhadap bermacam-macam masalah $83 \%$, bekerja mandiri $78 \%$, dapat mempertahankan pendapatnya $69 \%$, bekerja sama dalam mencari dan memecahkan masalah $91 \%$. Peningkatan ini terjadi karena materi pokok bahasan kerja sama internasional dipelajari dengan metode yang sesuai yaitu metode Quantum teaching. Sehingga siswa lebih aktif, kreatif, karena metode Quantum teaching melibatkan siswa untuk selalu aktif dalam langkah langkah metode tersebut. Selain itu metode Quantum teaching juga mengaitkan materi pelajaran dengan kehidupan sehari-hari sehingga siswa lebih mudah memahami materi yang dipelajari serta motivasi belajar siswa lebih meningkat. 
Faktor penghambat pada penelitian ini adalah masih belum siapnya siswa menghadapi situasi pembelajaran yang baru diterapkan oleh peneliti baik itu dalam hal kurang siapnya siswa dalam menghadapi situasi yang baru yang dilakukan oleh peneliti, belum siapnya siswa melakukan suatu tindakan tanpa diminta oleh peneliti, ada beberapa siswa yang belum siap menghadapi perubahan dalam gaya mengajar.

Faktor pendukung selama penelitian ini berlangsung adalah banyak siswa yang senang dalam mengikuti pelajaran dengan penggunaan metode yang diterapkan oleh peneliti yaitu Quantum teaching.

Dari pembelajaran tersebut dapat disimpulkan bahwa penggunaan metode Quantum teaching sangat efektif dalam pembelajaran IPS pada sub pokok bahasan Kerja Sama Internasional, karena dengan metode ini siswa menjadi lebiih aktif sehingga meningkatkan motivasi pada saat pembelajaran berlangsung. Dari hasil yang ditemukan oleh peneliti maka dapat disimpulkan bahwa hipotesis yang diajukan oleh peneliti adalah motivasi belajar siswa dapat ditingkatkan melalui penggunaan metode Quantum teaching pada sub pokok bahasan Kerja Sama Internasional di kelas Kelas IX-A SMP Negeri 12 Tanjung Balai Tahun Ajaran 2014/2015.

\section{SIMPULAN DAN SARAN}

\section{Simpulan}

Berdasarkan hasil penelitian dan pembahasan maka dapat disimpulkan hal sebagai berikut:

1. Motivasi belajar siswa mengalami peningkatan setelah diberikan perlakuan dengan menggunakan metode Quantum teaching pada saat kegiatan pembelajaran.

2. Metode Quantum teaching efektif digunakan pada pelajaran IPS khususya dalam pokok bahasan Kerja Sama Internasional.

3. Dapat diketahui motivasi belajar siswa pada siklus I menunjukkan bahwa sebesar 55\% siswa yang memiliki indikator tekun menghadapi tugas, 50\% siswa yang memiliki indikator ulet menghadapi kesulitan, 60\% siswa yang memiliki indikator menunjukkan minat yang tinggi terhadap berbagai macam masalah, 40\% siswa yang memiliki indikator bekerja mandiri, 39\% siswa yang memiliki indikator dapat mempertahankan pendapatnya, 58\% siswa yang memiliki indikator bekerja sama dalam mencari dan memecahkan masalah soal-soal. Dengan demikian, setelah diadakan tindakan pada saat proses pembelajaran dapat disimpulkan pada hasil tindalan siklus II yaitu sebesar $84 \%$ siswa yang memiliki indikator tekun menghadapi tugas, $77 \%$ siswa yang memiliki indikator ulet menghadapi kesulitan, $83 \%$ siswa yang memiliki indikator menunjukkan minat yang tinggi terhadap berbagai macam masalah, $78 \%$ siswa yang memiliki indikator bekerja mandiri, 69\% siswa yang memiliki indikator dapat mempertahankan pendapatnya, $91 \%$ siswa yang memiliki indikator bekerja sama dalam mencari dan memecahkan masalah soal-soal.

4. Secara garis besar dapat disimpulkan bahwa metode Quantum teaching adalah metode yang mampu menuntun siswa untuk meningkatkan motivasi belajar. 


\section{Saran}

berikut:

Berdasarkan hasil penelitian dan pembahasan dapat disarankan hal sebagai

1. Agar guru meningkatkan motivasi belajar siswa dengan menggunakan metode Quantum teaching.

2. Disarankan agar guru menggunakan metode Quantum teaching dalam mengajar baik pada pelajaran IPS pokok bahasan Kerja Sama Internasional maupun mencobanya pada pelajaran lain.

3. Demikian pula agar kepala sekolah mengembangkan atau melatih para guru agar terampil menggunakan berbagai macam metode mengajar terutama metode Quantum teaching.

4. Pada peneliti lain yang berminat disarankan untuk meneliti tentang efektifitas metode Quantum teaching dalam meningkatkan motivasi belajar, pada mata pelajaran lain diluar IPS.

\section{DAFTAR PUSTAKA}

[1] Arikunto, Suharsimi.2007.Manajemen Penelitian.Jakarta. Rineka Cipta

[2] ---------------------.2008.Penelitian Tindakan Kelas.Jakarta.Bumi Aksara

[3] A'la,Miftahul.2010.Quantum Teaching.Yogyakarta.DIVA Press

[4] Dewi, Rosmala.2009.Penelitian Tindakan Kelas.Medan.Program Pascasarjana UNIMED

[5] DePorter, Bobbi. Dkk.2010.Quantum Teaching.Bandung.Kaifa

[6] Djamarah,Syaiful Bahri.2008.Psikologi Belajar.Jakarta.Rineka Cipta

[7] -----------,Syaiful Bahri.2000.Guru dan anak didik dalam interaksi edukatif. Jakarta.Rineka Cipta

[8]Heldinawati.2010. Penerapan Metode Eksperimen Dalam Meningkatkan Motivasi Belajar Siswa Pada Mata Pelajaran Sains Kelas IVb SD Negeri 060820 Medan Kota.Unimed (Tidak diterbitkan)

[9] Lubis,Satria Hadi.2009.Total Motivation.Yogyakarta.PRO-YOU

[10] Purwanto,M.Ngalim.1996.Psikologi Pendidikan. Bandung : Remaja Rosdakarya

[11] Sardiman,A.M.2003.Interaksi Motivasi Belajar.Jakarta.Raja Grafindo Persada

[12] Sitanggang, I. 2007. Konsep Dasar Ilmu Pengetahuan Sosial. Medan. Universitas Negeri Medan

[13] Sukardi. 2008. Metodologi Penelitian Pendidikan.Jakarta. Bumi Aksara

[14] Trianto.2010.Model Pembelajaran Terpadu.Jakarta.Bumi Aksara

[15] Uno,Hamzah B.2009.Teori Motivasi dan Pengukurannya.Jakarta.Bumi Aksara

[16] Winardi, Tantya Hisnu P. 2008. Ilmu Pengetahuan Sosial Untuk SD/MI Kelas 4. Medan. Madju Medan Cipta. 